Western New England University School of Law Digital Commons @ Western New England University School of Law

2016

\title{
Inequality, Discrimination and Sexual Violence in US Collegiate Sports
}

Erin E. Buzuvis

Western New England University School of Law, ebuzuvis@law.wne.edu

Kristine Newhall

University of Massachusetts Amherst Isenberg School of Management, knewhall@isenberg.umass.edu

Follow this and additional works at: http://digitalcommons.law.wne.edu/facschol

Part of the Education Law Commons, Entertainment, Arts, and Sports Law Commons, Labor and Employment Law Commons, and the Law and Gender Commons

\section{Recommended Citation}

Erin Buzuvis \& Kristine Newhall, Inequality, Discrimination and Sexual Violence in US Collegiate Sports, in GLOBAL CORRUPTION REPORT: SPORT (Gareth Sweeney \& Kelly McCarthy, eds., 2016).

This Book Chapter is brought to you for free and open access by the Faculty Publications at Digital Commons @ Western New England University School of Law. It has been accepted for inclusion in Faculty Scholarship by an authorized administrator of Digital Commons @ Western New England University School of Law. For more information, please contact pnewcombe@law.wne.edu. 


\title{
5.4
}

\section{Inequality, discrimination and sexual violence in US collegiate sports}

\author{
Erin Buzuvis and Kristine Newhall'
}

College athletics is a popular cultural institution, attracting thousands of participants and millions of fans each year. Yet, examining US college athtetics reveals a pattern of inequality, discrimination and abuse, which operates to foreclose women's access and suppress women's interest in athletic participation and leadership. This chapter examines three genderrelated issues of integrity in college athletics: gender discrimination in athletic participation and opportunity; barriers to leadership for women coaches and administrators; and the relationship between athletics and sexual violence at college and universities.

\section{Discrimination in athletic participation and opportunity}

Colleges and universities provide the majority of athletic opportunities to men, ${ }^{2}$ even though women make up a majority of college students. ${ }^{3}$ This imbalance exists despite the fact that Title IX, a federal statute passed in 1972, prohibits discrimination on the basis of sex in educational programmes that receive federal financial assistance. ${ }^{4}$ Title IX is credited with increasing the number and quality of opportunities for female athletes, yet many schools still struggle with compliance. Under the law, colleges and universities must provide equitable athletic opportunities to men and women using one of three possible compliance tests. ${ }^{5}$ Some institutions seek to avoid the expense of compliance with any of these tests - which generally require ${ }^{6}$ adding new opportunities for women - by manipulating their rosters to give the appearance of providing a proportionate distribution of athletic opportunities. For example, litigation exposed one university's practice of 'triple-counting' female runners as members of cross-country, winter track and spring track teams, even though, for many of the runners, the track teams operated as an 'adjunct' to the cross-country team: merely a source of offseason training rather than as a source of athletic opportunity in their own right. ${ }^{7}$ Colleges and universities have over-counted women's athletic opportunities, as well as under-counting those for men, ${ }^{8}$ to create the appearance of proportlonality and thus avoid the legal obligation to create new athletic opportunities for women that would exist under either of the two atternative measures of compliance.

Title IX also requires that athletics departments provide equal treatment to men's and women's programmes in the aggregate, as measured by factors such as the quality of 
facilities, equipment and uniforms; the schedule of games and practices; the quality of coaching and of the academic and medical services received; and publicity and promotion. ${ }^{9}$ Relatedly, the law requires athletics departments to distribute scholarship dollars proportionately to the percentage of athletes of each sex. ${ }^{10}$ The fact that men's athletic programmes generally receive more resources than women's, ${ }^{11}$ as well as the fact that female college athletes receive a smaller share of scholarship dollars, ${ }^{12}$ suggests that there is likely widespread non-compliance with these requirements as well. ${ }^{13}$ Although the revenue-generating potential of men's football and basketball may explaln why schools are willing to provide greater support to men's programmes, Titte IX does not permit athletics departments to provide inferior treatment to women's teams on the basis of consumer preferences for men's sports. ${ }^{14}$

\section{Barriers to leadership for women coaches and administrators}

Women constitute a minority (23 per cent) of head coaches at the college level, and are similarly under-represented at the highest levels of administration. Notably, women are even minorities among coaches of women's teams ( 43 per cent), and are hardly represented at all ( 3 per cent) among coaches of men's teams. ${ }^{15}$ Additionally, whlle African-American female athletes and coaches are not under-represented relative to the population data, their particlpation is overwhelmingly confined to basketball and running sports, suggesting that race and gender combine to erect barriers to entry into other sports. ${ }^{16}$

Several cases have revealed how retaliation, hostile environments and double standards operate to exclude women from the ranks of coaches and administrators. ${ }^{17}$ For example, litigation exposed several instances in which athletics administrators at California State University, Fresno, retaliated against female coaches and administrators for advocating for gender equity on behaif of themselves and their players. ${ }^{18}$ The lawsuits also revealed the athletics department's homophobic atmosphere, tolerance for sexual harassment and tendency to single out female coaches for discipline. The plaintiffs in these cases prevailed in multi-million-dollar settlements and jury awards. ${ }^{19}$ While these cases and others show that it is possible to use Title $\mathrm{IX}$ and other anti-discrimination laws to successfully challenge these practices, the high soclal and financial costs of challenging inequality, as well as the difflculty proving discriminatory motivation, deter many potential plaintiffs from pursuing legal recourse. The fact that coaches of women's teams earn less than those of men's teams has also proved impervious to legal recourse, even though it suggests the possibility of pay discrimination against female coaches, who are virtually excluded from the opportunities in higher-paying jobs coaching men. ${ }^{20}$

\section{Student-athletes and sexual violence}

Sexual assault and violence is an epidemic across American college campuses. ${ }^{21}$ Although there is no definitlve data ${ }^{22}$ that athtetes - at any level - are more prone to violence than their non-athlete peers, the culture of college athletics has created a unique environment in which there has been significant mishandling of sexual violence accusations against student athletes. This is the result of both a culture of entitlement for student athletes and a win-at-allcosts mentality within athletics departments and schools. ${ }^{23}$

Historically, student athletes have received various privileges and perks, often in violation of National Colleglate Athletic Association (NCAA) rules and Titie IX, including preferential housing, gifts and money from alumni, and unique academic considerations including special classes, scheduling and assignments. ${ }^{24}$ Although some of these have been eliminated, the 
sentiment remains that athletes, and by extension athletics departments, occupy a high position in the campus hierarchy. One result of this has been that student-athletes who are accused of sexual assault and violence are often shielded from formal investigations, or even basic questioning, after an incident. In 2010, at the University of Notre Dame, the campus police were not allowed access to a football player who had been accused of rape because he was in athletics department facilities. ${ }^{25}$

One explanation for the practices that privilege student-athletes is the increasing pressure on athletics departments to be successful on the playing field in order to increase athletics department revenue via sponsorships, television rights, alumnl donations and, potentially, Increased student enrolment. The win-at-all-costs mentality that results has shielded accused student-athletes whom coaches, administrators and even fans believe are essential for achieving or maintaining winning traditlons and providing entertainment. Thus they are willing to bend, stretch or ignore the rules governing the handling of reported sexual assaults when the accused are student-athletes. Evidence of this can be seen at the abovementioned University of Notre Dame, as well as at Florida State University and the University of Missouri. ${ }^{26}$

The visibility of big-time college athletics programmes and their star athletes has played a significant role in the recent awareness about campus sexual assauit in the United States, however, as seen in the public attention to several high-profile legal cases. ${ }^{27}$ In 2011 the Office for Civil Rights (OCR), a sub-agency of the US Department of Education, responsible for the oversight of Title IX, issued a 'Dear Colleague' letter that explicitly states the responsibilities of schools under Title IX to investigate claims of sexual violence. This letter of clarification was motivated in part by cases involving student-athletes, including a 2001 university-sanctioned party at the University of Colorado for football players and recruits at which two female students reported being raped. ${ }^{28}$ The 'Dear Colleague' letter states that all schools must institute proper procedures for investigating accusations, and notes that they 'must apply to all students, including athletes'. Schools are required to do their own independent investigations, and 'complaints must not be addressed solely by athletics department procedures'.29 The Colorado case ended with a large settlement for the victims and changes to the university's policies and procedures regarding the investigation of incidents.

Nonetheless, athletics departments continue to protect athletes accused of sexual violence, often in violation of the OCR's mandate that schools 'take immediate and effective steps to end sexual harassment and sexual violence'. 30 These illegal practices include dismissing student-athletes from the team but allowing them to remain on campus, facilitating transfers to new schools by exempting them from their athletic commitment, handling accusations solely within athletic departments, not reporting incidents to the proper university offlcials and delaying investigation until an athlete's season is over. These are all ongoing practices, as evidenced in cases in the past ten years including at Florida State University, the University of Oregon, the University of Missouri, the University of Tulsa and the University of Notre Dame. ${ }^{31}$

\section{Conclusion}

There are a number of remedies that can mitigate the problems within college athletics related to discrimination, inequality and sexual violence. Some of these remedies require government intervention. For example, the Department of Education could engage in more aggressive Title IX enforcement to ensure that institutions are held accountable for non-compliance even when victims of discrimination are deterred from filing lawsults by the associated financial, emotional, social and professional costs. Congress could put pressure on the NCAA, via an 
exemption from antitrust law, for example, to reform itself in such a way that reduces the commercialised nature of college athletics, thus reducing economic pressure on athletics departments to engage in the corrupt practices discussed above.

Colleges and universities could do a better job of policing themselves, such as by agreeing to condition NCAA membership status on Title IX compliance. As a step in this direction, the NCAA could restore the self-study process it once required of its Division I members, which conditioned membership on the institution's ability to evaluate and demonstrate its commitment to gender equity across a variety of measures. The NCAA could also implement policles that promote transparency in the handling of cases of athletes accused of assault, including penalising institutions that are found to have sheltered athletes from discipline or that have accepted the transfer of student-athletes found responsible for sexual violence. ${ }^{32}$

Colleges and universities could also improve the education and training they provide to staff on how to attain and sustain equitable participation opportunities, combat the implicit bias that serves as a barrier to women's athletic leadership, and effectively carry out their duties to report and address accusations of sexual violence.

Finally, the public in general, including fans, alumni, students and parents, have a role to play. By choosing carefully which college athletics programmes to attend and support, they can increase the pressure on universities to denounce and desist the inequitable allocation of resources, biased hiring practices and tolerance of sexual violence. Withholding support from athletics programmes that engage in these practices will ensure that they lack the resources to continue to engage in them.

\section{Notes}

1 Erin Buzuvis is a professor of law at Western New England University, Springfield, Massachusetts, and Kristine Newhall is a lecturer in sport management at the University of Massachusetts, Amherst. Together they founded and contribute to the Title IX Blog.

2 See National Collegiate Athletic Association, Student-Athlete Participation 1981/822013/14: NCAA Sports Sponsorship and Participation Rates Report (Indianapolis: NCAA, 2015), pp. $75-76$ (reporting a total of 207,814 opportunities in women's sports and 271,055 in men's).

3 Natlonal Center for Education Statistics, 'Digest of education statistics', table 303.10 , http://nces.ed.gov/programs/digest/d13/tables/dt13_303.10.asp.

4 Code of Laws (US), Title 20, chapter 38, § 1681: 'Sex', www.law.cornell.edu/uscode/text/ 20/1681.

5 First, they may comply by showing that the distribution of athletic opportunities is proportionate to the percentage of each sex in the student body. Alternatively, they may comply by showing a 'history and continuing practice' of expanding athletic opportunities for women as 'the underrepresented sex'. Another possibility is that they may demonstrate that they offer enough athletic opportunities to fully satisfy the interests and abilities of the under-represented sex. Department of Health, Education and Welfare, 'Policy interpretation: Title IX and intercollegiate athletics', Federal Register, vol. 44 (11 December 1979), pp. 71413,71418 .

6 As an alternative to adding opportunities for women, it is possible for institutions to comply with the proportionality prong by contracting opportunitles for men, as this practice is not prohibited by Title IX or any law. Nevertheless, notwithstanding the fact that the Department of Education calls cutting men's teams a 'disfavored' compliance, institutions regularly blame Title IX for such decisions rather than acknowledge the fact that the law preserves institutions' own autonomy to decide whether to comply by adding teams for women instead of cutting teams for men.

7 Biediger v. Quinnipiac University, 728 F. Supp. 2d62, 101-108 (D. Conn. 2010). 
8 New York Times (US), 'College teams, relying on deception, undermine gender equity', 25 April 2011, www.nytimes.com/2011/04/26/sports/26titleix.htm/? $r=0$.

9 US Code of Federal Regulations, 34 C.F.R. 106.41(c).

10 US Code of Federal Regulations, 34 C.F.R. 106.37(c).

11 National Collegiate Athletic Association, Gender-Equity 2004-2010: NCAA Gender-Equity Report (Indianapolis: NCAA, 2012).

12 lbid.

13 Erin Buzuvis and Kristine Newhall, 'Equality beyond the three-part test: exploring and explaining the invisibility of Title IX's equal treatment requirement', Marquette Sports Law Review, vol. 22 (2012).

14 Erin Buzuvis, 'Athlete compensation for women too? Title IX implications of Northwestern and O'Bannon', Journal of College and University Law, vol. 41 (2015).

15 Vivian Acosta and Linda Carpenter, 'Women in college sport: a longitudinal, national study - thirty-seven year update, 1977-2014', http://acostacarpenter.org//2014\%20Status\%20 of\%20Women\%20in\%20Intercollegiate\%20Sport\%20-37\%20Year\%20Update\%20-\%20 1977-2014\%20.pdf.

16 Richard Lapchick, 'The 2012 racial and gender report card: college sport', www.tidesport. org/RGRC/2012/2012_.College. RGRC.pdf.

17 Erin Buzuvis, 'Sidelined: examining bariers to women's leadership in college athletics through the lens of Title IX retaliation cases', Duke Journal of Gender Law and Policy, vol. 17 (2010).

18 lbid.

19 Ibid.

20 NCAA (2012).

21 Mother Jones (US), 'This new study shows sexual assault on college campuses has reached "epidemic" levels', 20 May 2015, www.motherjones.com/mixed-media/2015/05/ campus-sexual-assault-study; Kate Carey, Sarah Durney, Robyn Shepardson and Michael Carey, 'Incapacitated and forcible rape of college women: prevalence across the first year', Journal of Adolescent Health, vol. 56 (2015), pp. 678-680.

22 Findings from several studies suggest that college athletes may commit sexual assault at rates higher than their non-athlete undergraduate peers and/or that male athletes in certain sports (that is, football and wrestling) may demonstrate higher levels of sexual aggression. These findings have not been replicated, however, as researchers face significant constraints in the collection of data (such as privacy rights and under-reporting).

23 New York Times (US), 'Errors in inquiry on rape allegations against FSU's Jameis Winston', 16 April 2014, www.nytimes.com/interactive/2014/04/16/sports/errors-in-inquiry-on-rapeallegations-against-fsu-jameis-winston.html; Huffington Post (US), 'University of Missouri mishandled sexual assault case, review finds', 11 April 2014, www.huffingtonpost.com/ 2014/04/11/missouri-sexual-assault-review-university. n.5134699.htmi; The Big Lead (US), 'Missouri failed to conduct Titte IX investigation on sexual assault allegation against football player', 21 August 2014, http://thebiglead.com/2014/08/21/missouri-failed-to-conducttitle-ix-investigation-on-sexual-assault-allegation-against-football-player.

24 Huffington Post (US), 'These college athletes say they deserve special treatment', 2 September 2014, www.huffingtonpost.com/2014/09/02/college-athletes-deservespecial-treatment $n \_5749758 . h t m l$.

25 Kirby Dick, The Hunting Ground (Callfornia: RADiUS-TWC, 2015).

26 Ibid., note 23.

27 ESPNW (US), 'Athletic departments handing sexual assault cases: never a good idea', 21 August 2014, http://espn.go.com/espnw/news-commentary/article/11386174/whyathletic-departments-clueless-handling-sexual-assaults; ESPN (US), 'Outside the lines: Missouri, Tulsa, southern Idaho face allegations they did not investigate Title IX cases', 25 August 2014, hitp://espn.go.com/espn/ot//story//id/11381416.

28 ESPN (US), 'Timeline: Colorado recruiting scandal', 27 May 2004, http://sports.espn. go.com/ncf/news/story?id $=1803891$. 
29 US Department of Education, 'Dear Colleague letter: Office of the Assistant Secretary', 4 April 2011,www2.ed.gov/about/offices/list/ocr/letters/colleague-201104.html.

30 lbid.

31 Huffington Post (11 April 2014); The Big Lead (2014); New York Times (2014); Huffington Post (US), "Notre Dame, stung by "The Hunting Ground," is under US investigation for sexual harassment cases', 17 April 2015, www.huffingtonpost,com/2015/04/17/notredame-sexual-harassment-hunting-ground $n_{-} 7082702 . h t m /$; USA Today, 'Ex-NFL player's son, Patrick Swilling Jr., implicated in sexual assault lawsuit', 18 August 2014, www. usatoday.com/story/sports/ncaab/2014/08/18/patrick-swilling-tulsa-sexual-assault-lawsuittitle-ix/14104075; The Oregonian (US), 'University of Oregon and Dana Altman sued over alleged sexual assault', 8 January 2015, www.oregon/ive.com/ducks/index.sst/2015/01/ university_of_oregon_and_dana.html.

32 The Southeastern Conference, one of the most powerful intercollegiate athletics conferences in the United States, recently instituted a policy preventing the acceptance of transfer student-athletes who had been found guilty of 'serious misconduct', including sexual assault and domestic violence, at their previous institutions. It remains unknown whether other conferences or the NCAA will adopt similar policies. Sports Illustrated (US), 'SEC bars transfer athletes dismissed for "serious misconduct"', 29 May 2014, www.si.com/collegefootball2015/05/29/sec-transfer-rule-serious-misconduct-domestic-violence. 